\title{
Online Matriculation Program (OMaPro): Improving the Readiness of Prospective School Principals
}

\author{
Juwita R., , Siswandari, Joyoatmojo S., Wiranto \\ Doctoral Program in Department of Education Postgraduate Faculty of Teacher Training and Education, Sebelas Maret University, \\ Indonesia
}

Received May 22, 2020; Revised July 15, 2020; Accepted July 29, 2020

\section{Cite This Paper in the following Citation Styles}

(a): [1] Juwita R., Siswandari, Joyoatmojo S., Wiranto , "Online Matriculation Program (OMaPro): Improving the Readiness of Prospective School Principals, "Universal Journal of Educational Research, Vol. 8, No. 9, pp. 4340-4347, 2020. DOI: 10.13189/ujer.2020.080961.

(b): Juwita R., Siswandari, Joyoatmojo S., Wiranto (2020). Online Matriculation Program (OMaPro): Improving the Readiness of Prospective School Principals. Universal Journal of Educational Research, 8(9), 4340-4347. DOI: 10.13189/ujer.2020.080961.

Copyright $\bigcirc 2020$ by authors, all rights reserved. Authors agree that this article remains permanently open access under the terms of the Creative Commons Attribution License 4.0 International License

\begin{abstract}
School principals play an important role in developing high-performing schools. To meet the challenges of the 21 st century, they need quality preparation and professional learning before their assignments. However, there are significant challenges to find out high quality people who are physically, mentally, and emotionally ready to join preparation training course. This study aims to examine the effect of the Online Matriculation Program (OMaPro) on the readiness of prospective school principals for Principal Preparation Training (PPT). A pretest-posttest quasi-experimental design was used in the study, in which a total of 189 prospective school principals participated in the pretest and posttest of the first PPT cohort. 129 prospective school principals participated in both the pretest and posttest, with 99 students taking OMaPro before training, and with 30 who had never followed a matriculation program before training serving as the control group. The results of the study show that OMaPro positively influenced the cognitive, behavioral and emotive-attitude readiness of the participants. Unfortunately, the program cannot run in rural areas because of the lack of internet access. The results should be helpful for prospective school principals to prepare themselves before training, and also for education authorities and policy makers in order to maximize the training results and manage the training programs.
\end{abstract}

\begin{tabular}{|c|c|c|}
\hline Keywords & Matriculation, & Learning \\
\hline $\begin{array}{l}\text { Prospective } \\
\text { Training }\end{array}$ & School Principal, & Principal \\
\hline
\end{tabular}

\section{Introduction}

\subsection{Principal Preparation Training (PPT)}

The role of school principals is critical in preparing students to meet the challenges of the 21 st century. School principals have two important roles, as instructional leaders and as school managers [27]. They need to ensure that schools are operational and safe, and foster a team work culture in which teachers and staff can serve students as they pursue their academic goals in the era of globalization and rapid technological advances [17]. Sharp [27] p.9, states that "although instructional leadership remains the central expectation of the principalship, the scope of the school-site management role has grown substantially over the years".

The important roles of school principals require qualified people who meet administrative and substantive requirements. For example, in Hong Kong, they are required to have five years' teaching experience and the leadership skills needed for education development in the 21 st century. The principal preparation program contains three parts: 1) a needs analysis to ascertain the strengths and weaknesses of the participants; 2) a 72 hour course designed to equip participants with leadership competences; and 3) presentation of career highlights in the form of a reflective journal [20]. Another example is the Swedish principal preparation program, which in general is followed by educators with master's or doctoral degrees in subjects appropriate for the program. The course covers themes including 1) legislation on schools and the role of exercising the functions of authority; 2) 
management by goals and objectives; 3 ) school leadership; and 4) supervision [21]. In the case of Finland it provides a training qualification in the form of short-term training in school administration, leadership, and legislation, combined with practical fieldwork [19]. Teaching experience, educational background, and courses/trainings combined with practical fieldwork are various activities in principal preparation training (PPT).

The research conducted by ACDP 2016 analyzed Principal Preparation Program Implementation in Indonesia as a whole from recruitment, administrative selection, academic selection, training IN-ON-IN, and the issuance of certificate. This research found that principal preparation program in Indonesia was considered 'very effective' by more than half of the participants [1]. Principal preparation programs in Hong Kong, Sweden, Finland, and Indonesia contain different activities, but courses/training is common elements.

Kirkpatrick \& Kirkpatrick [14] stated that training aims at equipping skills, knowledge, or attitudes to improve job performance. Principal preparation training aims to equip potential teachers with school principal competencies. Related to improving the competency of principals, The International Study of Principal Preparation (ISPP), a study conducted by the University of Calgary in Canada in early 2000 involving in 14 countries, examines examples of principal preparation experiences and examines professional learning approach. This international research shows that principals need core skills and abilities in education and management leadership to carry out their roles in their respective schools.

The ISPP found that new principals in 14 countries faced the same problems. The problems faced include how to implement the concepts of leadership and managerial, introducing new technologies in the learning process and school administration, negotiating with the government to get help to fulfill needs; and resolve conflicts with teachers and students' parents. The findings that emerge in the ISPP indicate that there needs to be a stronger theoretical and empirical foundation for implementing leadership and managerial practices for prospective principals [1].

Indonesia has implemented the PPT since 2010. The program starts with administrative selection. Administrative requirements to recruit potential teachers with a minimum of a bachelor degree, certified teacher, 5 years teaching experience, and have managerial experience. Participants who pass the administrative and academic selection, will join 300 hours of a principal preparation training. The training usually requires 3-4 months to complete. The training material consists of school management, instructional leadership, academic supervision, and entrepreneurship. The training aims to improve motivations, develop teachers' knowledge and skill to become school principal.

\subsection{Readiness of Prospective School Principals}

Training is found in almost all principal preparation programs as an activity to transfer leadership and managerial competencies $[30,26,20]$. The important part of training is the learning process, in which aspiring principals learn certain aspects of principalship. Schunk [24] states that individuals learn best when they are physically, mentally, and emotionally ready. This assumption is based on Thorndikes' Law of Readiness, which states that individuals will learn new knowledge/skills when they have mastered the prerequisites. Baharudin, [2] and Slameto [28] define readiness as the adequency of an individual's existing capacity in relation to some instructional objective. Maddox, Forte, \& Boozer [16] state that not only prerequisite knowledge and skill factors contribute to learning readiness, but also emotive-attitude factors.

Based on these theories, the key to successful PPT is the readiness of prerequisite knowledge, skills, and attitudes. When the prospective school principals are ready to join PPT, they will learn better and transfer their knowledge and skills when appointed as principals [11]. In fact, the problem of the readiness of prospective school principals arises due to a lack of motivation, prerequisite knowledge and skills.

In term of motivation, Sachs (cited in [20], p.1840) states that it is difficult to attract potential teachers to become school principals. There are at least three reasons why most teachers do not want to become principals: (1) principalship is stressful; (2) principals' salaries are low relative to the responsibilities of the position; and (3) the job is complex and time-demanding [5]. A previous study conducted by Hancock and Müller [6] established motivating and inhibiting factors with regard to PPT. The study revealed that teachers in both the USA and Germany were attracted to becoming principals because they would have a positive impact on students and teachers in learning environments, have the power to initiate changes, and have a chance to experience the professional and personal challenges of a leadership position. Factors that inhibited both US and German teachers from becoming principals included the large amount of paperwork/bureaucracy, the high number of commitments, the distance from students, the potential for litigation and the lack of autonomy. The study was similar to one conducted by Harris et al. [7] based on literature regarding motivators and inhibitors for public school principalship. Both studies reveal the lack of motivation among teachers to become principals and to join principal preparation programs.

In term of the prerequisite knowledge and skills of prospective school principals, previous research on 469 participants in the Indonesian Principal Preparation Training (PPT) found that their initial knowledge and skills were at a poor level, scoring only 39.96 out of a maximum score of 100 [10]. The lowest score was ICT utilization and monitoring evaluation (M \& E). Since PPT 
success and effectiveness can be influenced by prospective school principals' readiness [15], the way to achieve this need to be found.

Juwita and Siswandari [10] asked prospective school principals how to improve their readiness for training. The results showed approximately $15 \%$ suggested better time management in training. Another 9\% recommended that they needed competent trainers, while $19 \%$ suggested that training materials should be contextually based. Finally, the most popular solution (suggested by $46 \%$ of prospective school principals) was to design a matriculation program aimed at equipping them with the same initial PPT knowledge, skills, and motivation.

\subsection{Online Matriculation Program (OMaPro)}

Opinions on how to improve readiness recommended that such a matriculation program should be followed by the prospective school principals before attending training [10]. The term 'matriculation' is commonly used by schools or colleges to express a set of administrative and academic requirements that must be met by students before joining the learning process. Most research studies on matriculation programs are based on university courses, not training.

The matriculation program in America arises because there are problems with the low number of African American students taking doctoral programs in the field of social work. These minority African American students need greater attention in preparing them before taking lectures. The matriculation program is needed by the faculty to broaden students' insights and identify strategies that can be used to facilitate these minority black students [8]. The matriculation program is also carried out by the University of California at Berceley. Through the matriculation program, the University of California pays special attention to the increasing number of international students. This attention focuses on how best to prepare students before arrival, how to adjust this preparation to their expectations and experiences [29].

Campos, Ryn, \& Davidson [3] find gaps that extend to Latin male and female students. Although Latin student's access to college is increasing, male students fail more often during lectures. The implication is that six out of ten undergraduate degrees are accepted by female Latin students. This encourages the matriculation program carried out by the mentorship method. Senior students become mentors for junior students. Every week a mentor comes to guide the mentee in overcoming obstacles and discussing the problems faced at the beginning of the lecture. This mentorship program not only addresses academic problems, but also teaches how to cope with change and interact with the community. Based on the three studies, it can be concluded that matriculation is not a test, but an effort to facilitate new students to be ready to attend lectures and be ready to adapt to the environment and other student friends.
The matriculation program in principal preparation training is a new way of preparing candidates. It is an effective program for participants with different educational backgrounds [23] as it reduces disparities between participants, significantly increases the level of participant graduation and improves learning outcomes [22]. Matriculation programs have been positively correlated with learning achievement [25]. The form of program is a learning process with certain units of learning aimed at improving prior knowledge, skills, and motivation before principal preparation training. When school principal candidates are ready, they will learn better and achieve the training goals more easily.

\subsection{Aims of Study}

Optimizing readiness of prospective school principal is a key to successful PPT. However, prospective school principals in Indonesia have insufficient readiness before being appointed. Additionally, there is paucity of research that examines how online matriculation program effect training readiness and prospective school principals' achievements in the training. This study has also identified factors that contribute to the improvement of training quality. Therefore, this study aims to answer the following research question: "Is there a significant change in the readiness of prospective school principals for Principal Preparation Training (PPT) following implementation of the Online Matriculation Program (OMaPro)?.

\section{Materials and Methods}

\subsection{Participants and Procedure}

A pretest-posttest quasi-experimental design was used in the study, in which a total of 189 prospective school principals participated in the pretest and the posttest of the first PPT cohort. 129 took part in both the pretest and posttest, among 99 took "the OMaPro" before training and 30 students who had not previously taken a matriculation program before training served as the control group. Therefore, we used a sample of 78 participants in the experimental group and 30 participants in the control group. The experimental group was divided into three classes named after the districts in which the participants were located (Boyolali, Purworejo and Sleman) and the control group comprised the Magelang class.

For the pretest, the participants sat a test a week before the training. For the experimental group, the participants completed the test before they joined OMaPro. For the posttest, they sat the test at the end of OMaPro. OMaPro is an online learning program using the open source learning platform Moodle to engage prospective school principals in online activities and reading material before joining the PPT (see Figure 1). 


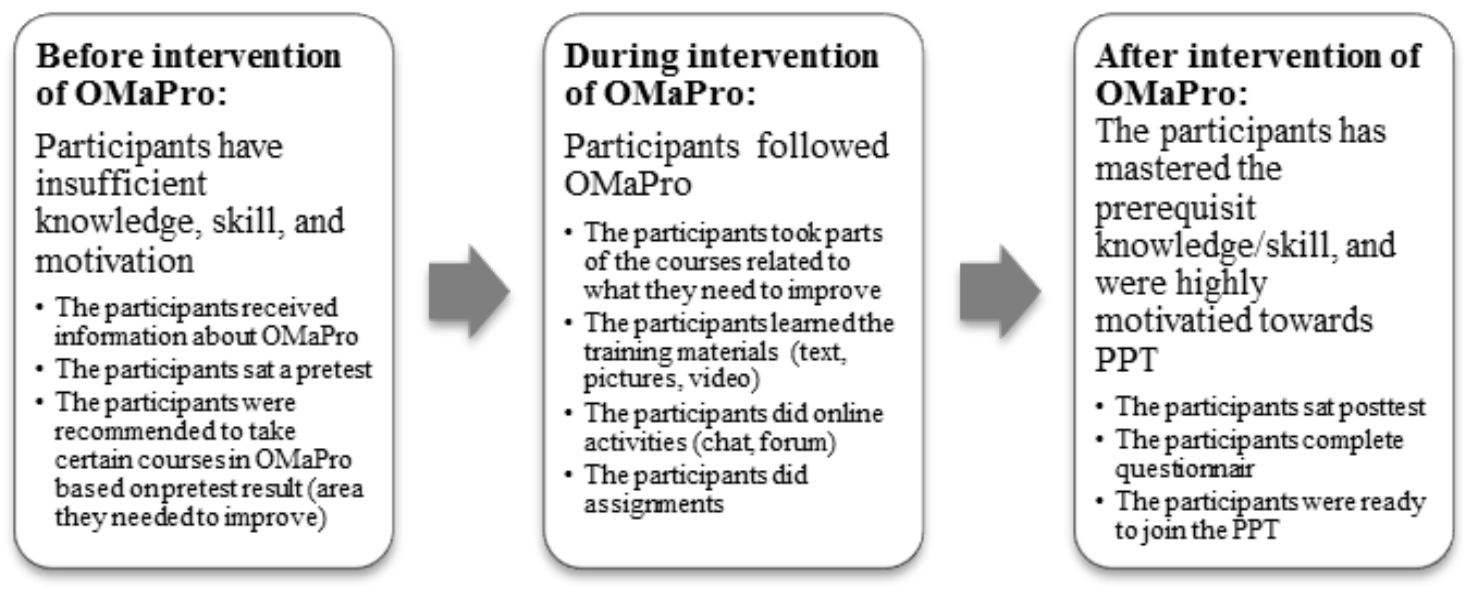

Figure 1. OmaPro implementation in PPT

\subsection{Instruments}

Holton et al. [8] p. 342 define training readiness as "the extent to which individuals are prepared to enter and participate in training". This training preparation includes cognitive, behavioral and emotive-attitude factors [16]. Based on these definitions, it is concluded that the indicators of training readiness are as shown in Table 1.

Table 1. Training readiness indicators

\begin{tabular}{|c|c|c|c|}
\hline Category & \multicolumn{2}{|r|}{ Indicators } & Instrument \\
\hline $\begin{array}{c}\text { Cognitive and } \\
\text { behavioral } \\
\text { factors }\end{array}$ & 2. & $\begin{array}{l}\text { Has good prior } \\
\text { knowledge of principal } \\
\text { competencies } \\
\text { Has managerial } \\
\text { experience/skills }\end{array}$ & Test \\
\hline $\begin{array}{l}\text { Emotive- } \\
\text { attitude factors }\end{array}$ & $\begin{array}{l}3 \\
4 \\
5\end{array}$ & $\begin{array}{l}\text { Has a good attention } \\
\text { Has good motivation } \\
\text { Has a good self- } \\
\text { confidence } \\
\text { Has good satisfaction }\end{array}$ & Questionnaire \\
\hline
\end{tabular}

The cognitive and behavioral items measure prior knowledge and skills in principal competencies, including managerial, supervisory, and entrepreneurial aspects. The item test was assessed by a validity and reliability test. The validity test shows that $r_{\text {count }}>r_{\text {table }}(0.3494)$, while the reliability test shows a very high score $(0.947)$. Based on these results, it is revealed that there is significant correlation value shown by $r_{\text {table }}$ or the correlation coefficient, which is higher than 0.3494. Therefore, the test items used in the study are valid.

Emotive-attitude indicators used in this study are derived from ARCS indicators: attention, relevance, confidence and satisfaction [13]. When motivation is combined with knowledge and skills, good readiness is achieved, which affects learning outcomes. The emotiveattitude factors are measured by Keller's ARCS model questionnaire which is examined by content validity. This content validity is assessed by expert judgment.

The Minitab program was utilised for the data analysis. In order to identify if there were any significant differences between the scores received in the pre- and posttests of the Boyolali, Purworejo and Sleman classes, a paired sample t-test was used with hypothesis $\mathrm{H}_{0}$ : $\mu \_$difference $=0$ and $\mathrm{H}_{1}: \mu \_$difference $>0$, where $\mu 1$ is posttest and $\mu 2$ is pretest. An independent sample t-test was utilised to measure the differences in the means of the post-post test scores of the Sleman and Magelang classes. The hypotheses are the null hypothesis $H_{0}: \mu_{1}-\mu_{2}=0$ and the alternative hypothesis $H_{1}: \mu_{1}-\mu_{2}>0$. The significance level used was 0.05 .

\section{Results}

Developing an online environment that will promote the accomplishment of instructional goals is not an easy task. There must be a clear hypothetical model that describes the instructional goals, syntax and evaluation. Joyce, Weil, \& Calhoun [9] state that when a teacher arranges and creates a learning behaviour with certain goals and systematic steps, a learning model needs to be designed. An online matriculation program is a model of learning which aims to improve students' readiness for PPT.

There are five activities in OMaPro: 1) specify target behaviour; 2) establish a baseline; 3) design a learning environment; 4) institute a learning process (intervention); and 5) evaluate the learning. The steps of OMaPro are derived from behavior modification program. Behavior modification program is a systemic way to establish the desirable behavior in the learner's daily life and to allow the new behavior to be transferred in the new situation [18]. Target behaviour can be found in the learning orientation, while students' baseline comes from the pretest scores at the beginning of the program. The learning environment is an online class at www.matrikulasicks.org using LMS Moodle, and the learning process consists of reading materials, watching videos, participating in discussions, and submitting assignments. Learning evaluation is made through a posttest at the end of the learning process. 
Based on Table 2 it found that the most highly needed materials were monitoring and evaluation, ICT, infrastructures, and teacher and staff management. The prospective school principals took the tests, read the materials, and discussed the material in OMaPro. These online activities aim to improve prior knowledge and skills, and to act as motivation as indicators of readiness for PPT. It was proved that the five lowest scores increased after the intervention of OMaPro.

Table 2. List of Score of Each Item

\begin{tabular}{|c|c|c|}
\hline Test Indicators & Pre-test & Post-test \\
\hline School plan & 28 & 67 \\
\hline School finance & 32 & 71 \\
\hline Curriculum development & 44 & 84 \\
\hline Student management & 66 & 86 \\
\hline Teacher and staff & 23 & 67 \\
\hline Infrastructures & 17 & 54 \\
\hline ICT & 17 & 88 \\
\hline Monitoring and Evaluation & 16 & 88 \\
\hline
\end{tabular}

The effectiveness of OMaPro was also proven by the following paired sample t-test. The Lilliefors normality test in the Boyolali class showed that $\mathrm{L}_{0}(0.126)<\mathrm{L}_{\text {table }}$ $(0.161)$, which means that the population is normally distributed. The paired sample t-test indicated that the pretest mean score was 44.56 and that of the posttest 66.32, with a p-value of 0.00 (Table 3). This proves that there is a high level of statistical difference in the average scores in learning readiness after OMaPro intervention $(\mathrm{p}<0.005)$.

Table 3. Results of the paired sample t-test for Boyolali class

\begin{tabular}{|c|c|c|c|}
\hline & Mean & St Dev & SE Mean \\
\hline Pre-test & 44.56 & 10.41 & 1.90 \\
\hline Post-test & 66.32 & 13.30 & 2.43 \\
\hline Difference & 21.75 & 14.80 & 2.70 \\
\hline \multicolumn{4}{|c|}{$\begin{array}{l}95 \% \text { CI for mean difference: }(27.28 ; 16.23) \\
\mathrm{T}-\mathrm{Test} \text { of mean difference }=0(\mathrm{vs} \text { not }=0): \mathrm{T}-\text { Value }=8.05 \mathrm{P}- \\
\text { Value }=0.000\end{array}$} \\
\hline
\end{tabular}

The population in Purworejo was also normal, because the Lilliefors normality test showed that $\mathrm{L}_{\mathrm{o}}(0.166)<\mathrm{L}_{\text {table }}$ $(0.200)$. The paired sample t-test in Purworejo proved that that there was a high level of statistical difference in the average scores obtained in learning readiness after OMaPro intervention $(p<0.005)$. There was significant progress from the pretest mean score of 36.84 to the posttest score of 66.08 (Table 4).

Table 4. Results of the paired sample t-test for Puworejo class

\begin{tabular}{|c|c|c|c|}
\hline & Mean & St Dev & SE Mean \\
\hline Pre-test & 36.84 & 7.22 & 1.70 \\
\hline Post-test & 66.08 & 11.45 & 2.70 \\
\hline Difference & 29.24 & 15.97 & 3.76 \\
\hline \multicolumn{4}{|c|}{$\begin{array}{l}95 \% \text { CI for mean difference: }(37.18 ; 21.30) \\
\text { T-Test of mean difference }=0(\text { vs not }=0): \text { T-Value }=7.77 \text { P- } \\
\text { Value }=0.000\end{array}$} \\
\hline
\end{tabular}

Sleman's population was normal, as the Liliefors normality test showed that $\mathrm{L}_{\mathrm{o}}(0.121)<\mathrm{L}_{\text {table }}(0.161)$. The paired sample t-test in Sleman proved that there was a high level of statistical difference in the average scores of learning readiness after OMaPro intervention $(p<0.005)$. The pretest means score was 56.44 and that for the posttest 77.54 (Table 5). There was therefore significant progress in learning.

Table 5. Results of the paired sample t-test for Puworejo class

\begin{tabular}{|c|c|c|c|}
\hline & Mean & St Dev & SE Mean \\
\hline Pre-test & 56.44 & 6.37 & 1.16 \\
\hline Post-test & 77.54 & 7.31 & 1.33 \\
\hline Difference & 21.10 & 9.15 & 1.67 \\
\hline $\begin{array}{l}\text { 95\% CI for mean difference: }(24.52 ; 17.68) \\
\text { T-Test of mean difference }=0(\text { vs not }=0): \text { T-Value }=12.63 \quad \text { P- } \\
\text { Value }=0.000\end{array}$ \\
\hline
\end{tabular}

The paired sample t-test results of the three experiment classes show that OMaPro significantly influenced the increase in knowledge and skills of the prospective school principals. The results were strengthened by the independent sample t-test of the posttest scores from the experiment class (Sleman) and the control group (Magelang). The independent sample t-test results show that the p-value of 0.00 is lower than $\alpha 0.05$, so it is concluded that the experiment group's achievement was higher than that of the control group.

Table 6. Results of the paired sample t-test for Puworejo class

\begin{tabular}{|c|c|c|c|}
\hline & Mean & St Dev & SE Mean \\
\hline Post-Sleman & 77.54 & 7.31 & 1.3 \\
\hline Post-Magelang & 65.6 & 14.1 & 2.6 \\
\hline Difference & 11.93 & 11.21 & 7.09 \\
\hline $\begin{array}{l}\text { 95\% lower bound for differece 7.09 } \\
\text { T-Value = 4.12 P-Value }=0.000\end{array}$ \\
\hline
\end{tabular}

Cohen's $d$ was used to calculate the standardized mean difference between two groups by subtracting the mean of one group from the other (Mean Post Sleman - Mean Post Magelang) and divide the result by the standard deviation (SD) of the population from which the groups were sampled ((77.54-65.6)/11.21=1.06). Based on Cohen's d result, OMaPro have "large effect size" in improving readiness of prospective school principals.

Table 7. Table of Coven's d

\begin{tabular}{|c|c|}
\hline Size of Effect & D \\
\hline Small & .2 \\
\hline Medium & .5 \\
\hline Large & .8 \\
\hline
\end{tabular}

The results from the questionnaire distributed to the Boyolali, Purworejo and Sleman classes revealed that OMaPro increased participants' motivation in training. 
For attention and relevance indicators, more than a half participants (56\% and 52\%) from Purworejo class said that they were very curious and very relevance. It was a highest score among three classes. Although confidence and satisfaction indicators were less than a half participants (39\% and 44\%), the score in Purworejo class was still the highest. Boyolali class was in moderate, and Sleman was in the lowest score (Table 8).

Table 8. The Result of ARCS Model Questionnaires

\begin{tabular}{|l|l|l|l|}
\hline Indicators & $\begin{array}{l}\text { Boyolali } \\
\text { Class }\end{array}$ & $\begin{array}{l}\text { Purworejo } \\
\text { Class }\end{array}$ & $\begin{array}{l}\text { Sleman } \\
\text { Class }\end{array}$ \\
\hline A (attention)\% & \multicolumn{5}{|l|}{} \\
\hline Very curious & $44 \%$ & $56 \%$ & $33 \%$ \\
\hline Curious & $56 \%$ & $44 \%$ & $67 \%$ \\
\hline R (relevance)\% & \multicolumn{5}{|l|}{} \\
\hline Very relevant & $33 \%$ & $52 \%$ & $22 \%$ \\
\hline Relevant & $67 \%$ & $48 \%$ & $78 \%$ \\
\hline C (confidence)\% & \multicolumn{5}{|l}{} \\
\hline Very confident & $37 \%$ & $39 \%$ & $15 \%$ \\
\hline Confident & $63 \%$ & $61 \%$ & $85 \%$ \\
\hline S (satisfaction)\% & $41 \%$ & $44 \%$ & $26 \%$ \\
\hline Very satisfied & $59 \%$ & $56 \%$ & $74 \%$ \\
\hline Satisfied
\end{tabular}

\section{Discussion}

Principals' competencies include not only what they do, but also what they know. For that reason, theory and practice should be brought together to ensure their effectiveness [4]. OMaPro aims to improve candidates' knowledge, skills and motivation before starting PPT prior to their assignment as principals.

Related to the increase in the prerequisite knowledge of prospective school principals, it found that the mean difference in the pretest and the post-test scores of the Boyolali class was 44.56 to 66.32 , an increase of around 22 points. The results of the paired sample t-test analysis using Minitab showed that the p-value of 0.00 was smaller than $\alpha=.05 . \mathrm{H}_{0}$ was therefore rejected and $\mathrm{H}_{1}$ accepted, as there was a significant influence of OMaPro on the readiness of the Boyolali class, especially that related to mastering prior PPT knowledge and skills.

In further findings, the pretest score of the Purworejo class was lower than the Boyolali class; the mean pretest score in the Purworejo class was 36.84, while that of the Boyolali class was 44.56. However, the mean posttest scores of the two classes are only slightly different (66.32 and 66.08), meaning the gain score of the Puworejo class is better than that of the Boyolali class.

The gain score was checked through the paired sample t-test to prove statistical significance. Paired sample t-tests were conducted using Minitab and showed that the $p$ - value of 0.00 was smaller than $\alpha=.05$. Based on this result, $\mathrm{H}_{0}$ was rejected and $\mathrm{H}_{1}$ was accepted, as there was a significant influence of the matriculation program on the readiness for learning in the Purworejo class, especially for mastering PPT knowledge and initial skills.

The pretest scores of the Sleman class were higher than those of the Boyolali and Puworejo classes. The mean pretest score of the Sleman class was 56.44, while for the Boyolali class it was 44.56 and for the Purworejo class 36.84. The mean score of the posttest in the Sleman class was the highest, at 77.54, while for the Boyolali class it was 66.32 and for the Purworejo class 66.08.

Paired sample t-tests were conducted using minitab and showed that the $p$-value of 0.00 was lower than $\alpha=.05$. Based on this result, $\mathrm{H}_{0}$ was rejected and $\mathrm{H}_{1}$ was accepted, as there was a significant influence of OMaPro on the readiness of the Sleman class, especially in relation to mastering prior PPT knowledge and skills. Cohen's d result also revealed that OMaPro has "large" effect size in improving readiness of prospective school principals.

Even though the Sleman class had the highest posttest score, its learning gain score was only 21.1 . The highest learning gain was in the Purworejo class (Table 8). This poses the interesting question of why the Purworejo class learnt better than the Sleman class. The high pretest score of the Sleman class means OMaPro could not be considered as an important part of PPT. OMaPro was simply followed as a formality. In the pretest the Purworejo class scored only 36.84 , so they followed OMaPro intensively. One Purworejo participant made the remark that "OMaPro is very useful for prospective school principals; it helps me know more about managerial competencies, and makes my IT literacy better than before, so I can't wait to join PPT'. The questionnaire responses show that in all the motivation indicators (attention, relevance, confidence and satisfaction), Purworejo was the most curious, relevant, confident and satisfied class (Table 7). This reveals that motivation affects learning gain.

Table 8. The Result of Paired Sample T-Test

\begin{tabular}{|c|c|c|c|c|c|}
\hline Classes & N & Mean & StDev & T-Value & $\begin{array}{c}\text { P- } \\
\text { Value }\end{array}$ \\
\hline Sleman & 30 & 21.1 & 9.15 & 12.63 & 0.000 \\
\hline Purworejo & 18 & 29.24 & 15.97 & 7.77 & 0.000 \\
\hline Boyolali & 30 & 21.75 & 14.8 & 8.05 & 0.000 \\
\hline
\end{tabular}

Daun (2004), and Aurell et al. (2005), cited in [21], found that the PPT had improved the participants' communication, evaluation, problem-solving and creative thinking skills. However, there was criticism that although the PPT had effects on emotive-attitude levels, cognitive and behavioral levels remained the same.

The findings in this study prove the effectiveness of OMaPro. There was a significant change in the cognitive, behavioral and emotive-attitude readiness of the prospective school principals before joining the PPT. This 
is in line with previous research by Kaptiningrum [12], who found matriculation programs had important implications for participants' achievements. The matriculation program developed by Kaptiningrum assisted participants in improving their prerequisite skills. Sahetapy [23]) also proved that matriculation programs are important for participants from diverse educational backgrounds, enabling them to have good entry behaviour in the learning process, which in turn leads to successful learning outcomes.

\section{Conclusions}

Training readiness concerns the extent to which individuals are prepared to enter and participate in training. OMaPro enables prospective school principals to be wellprepared for the PPT. Both the results of the paired sample t-test of the single group pre-posttest results, and the independent sample t-test of the post-posttest experiment and control group show that there was a significant change in the knowledge and skills of the prospective principals before and after intervention. The ARCS model questionnaire revealed that OMaPro improved the candidates' motivation for the PPT. There was also a side effect among the Purworejo participants, in that OMaPro increased their IT literacy, especially in online learning activities.

The study has limitations. OMaPro is limited to training participants in urban areas, as an internet connection and adequate infrastructure are needed. In terms of future research, it is recommended that matriculation programs should be disseminated to more participants in order to increase their readiness for principal preparation programs. Alternative solutions to improve readiness are urgently needed for those who come from rural areas.

\section{Acknowledgments}

Thanks to all the respondents who participated in this research and to The Institution of Principal Development and Empowerment for their research permission.

\section{REFERENCES}

[1] Analytical and Capacity Development Partnership. Evaluation Report of Principal Preparation Program, ACDP Indonesia, Jakarta. 2016

[2] Baharudin. Teori Belajar dan Pembelajaran (Teaching and learning theories). Yogyakarta: Arruz Media, 2007. In Indonesia

[3] Campos, E. E., Ryn, R. V., \& Davidson, T. J. Changing deficit narratives about young Latino men in Texas through a research based mentorship program. VUE, 5(2), 53-59,
2018.

[4] Darling-Hammond, L., LaPointe, M., Meyerson, D., Orr. M. T., \& Cohen, C. Preparing School Leaders for a Changing World: Lessons from Exemplary Leadership Development Programs. Stanford, CA: Stanford University, Stanford Educational Leadership Institute, 2007.

[5] Hancock, D., Hary, C., \& Muller, U. An investigation of factors impacting the motivation of German and US teachers to become school principals. Comparative \& International Education, vol 7(3) 352-363, 2012.

[6] Hancock, D.R. \& Müller, U. Different Systems: similar challenges? Factors Impacting the Motivation of German and US Teachers to Become School Leaders, International Journal of Educational Research, 48(5), 299-306, 2009.

[7] Harris, S., Arnold, M., Carr, C.S., Lowery, S. \& Worsham, S.E., Motivating and Inhibiting Factors of the Principalship in Three States, in C.S. Carr \& C.L. Fulmer (Eds) Educational Leadership: knowing the way, showing the way, and going the way, pp. 307-317. Lanham, MD: Scarecrow Education, 2004.

[8] Howard, S. Black first-generation social work doctoral students. Journal of Teaching in Social Work, 21 (2), 513$527,2017$.

[9] Joyce, B., Weil, M., \& Calhoun, E., Models of Teaching. Boston: Pearson Education, Inc., 2009.

[10] Juwita, R., \& Siswandari. Teacher's readiness in the new principal preparation programme (PPP). International Journal of Pedagogy and Teacher Education (IJPTE), vol 7 (2), 343-353, 2018.

[11] Kang, H., Kim, E., \& Park, S. The effect of learning goal orientation and training readiness. International Journal of Educational Management, 33(2), 265-275. 2019.

[12] Kaptiningrum, P. The effectiveness of the language matriculation program to improve the speaking skill of students of STAIBN Tegal. Shahih, 1 (2), 149-164, 2016. (in Indonesian

[13] Keller, J.M., Motivational design for learning and performance, London: Springer, 2010.

[14] Kirkpatrick, D. L., \& Kirkpatrick, J. D., Evaluating training programs. San Francisco, CAL: Berrett-Koehler Publishers, 2006.

[15] Kulik, C.T., Pepper, M.B., Roberson, L. and Parker, S.K. "The rich get richer: predicting participation in voluntary diversity training", Journal of Organizational Behavior, Vol. 28 No. 6, pp. 753-769, 2007.

[16] Maddox, M., Forte M., \& Boozer R., Learning readiness: an underappreciated yet vital dimension in experiential learning, Developments in Business Simulation \& Experiential Learning, Volume 27, p. 272-278, 2000.

[17] Manna, P. Developing excellent school principals to advance teaching and learning: Consideration for state policy. New York: The Wallace Foundation, 2015.

[18] Medsker, Karen L. \& Horldsworth, Kristina M. Models and Strategies for Training Design. Maryland: The International Society for Performance Improvement, 2001. 
[19] Ministry of Education. Improving School Leadership, Finland. Finland: Publication of the Ministry of Education. 2007.

[20] Ng, S. W., The leadership capacities of aspiring principals in Hongkong. Procedia Social and Behavioral Sciences, 1840-1844, 2010.

[21] Norberg, K. The Swedish national principal training programme: a programme in constant change. Journal of Educational Administration and History, 1-9., 2018.

[22] Rosliana, N., Permanasari, A., \& Sudargo, F. Gambaran hasil belajar matrikulasi kimia kesehatan di pogram studi S1 kesehatan masyarakat STIKES Dharma Husada Bandung (Description of the learning outcomes of health chemistry matriculation in the S1 public health study program STIKES Dharma Husada Bandung). Jurnal Pendidikan Matematika dan Sains, vol.2, 188-200, 2014. In Indonesia

[23] Sahetapy, M. Penerapan program matrikulasi Biologi Umum Fakultas Ilmu Pendidikan Tahun 2016/2017 (Implementation of the Biology matriculation program in Faculty of Education year 2016/2017). A Journal of Language, Literature, Culture, and Education (POLYGLOT), vol 14 (1), 97-105, 2018. In Indonesia
[24] Schunk, D. Learning Theories: an educational perspective. Boston: Pearson, 2013.

[25] Shah, R., Johnstone, C., Rappaport, D., Billello, L., \& Rappaport, W., Pre-matriculation clinical experience positively correlates with Step 1 and Step 2 scores. Advances in Medical Education and Practices, 707-711, 2018.

[26] Shantal,K.M.A, Halttunen, L.,Pekka, K, Sources of principals' leadership practices and areas training should emphasize: Case Finland. Journal of Leadership Education, pp. 29-51, 2014.

[27] Sharp, W., The Principal as School Manager. Lanham, Maryland: Scarecrow Press, 2003.

[28] Slameto, Belajar dan faktor-faktor yang mempengaruhi (Learning and its influencing factors). Yogyakarta: Rineka Cipta, 2003. In Indonesia

[29] Sokolik, M. In their words: Student preparation and perspectives on US study. The Catesol Journal, 16(3), 2332, 2015.

[30] Thody, A. with Pashiardis, P., Johansson, O. and Papanoum, Z., School Principal Preparation In Europe. International Journal of Education Management, 21 (1) pp. 37-53, 2007. 